\title{
Black Jesus, Religious Truth, and Tupac Shakur: BELIEF AND THE IRONY OF FAITH
}

\author{
Dustin Zielke, University of Victoria
}

\begin{abstract}
Tupac Shakur's black Jesus should be understood through a distinction between belief and faith. The point of this distinction is not merely a matter of semantics. Rather, it helps illustrate how black Jesus challenges us to re-imagine religious truth and recognize the powerful role of irony in religious matters. Religious belief is commonly understood as a belief in a religious reality, or something that is objectively true. Tupac's black Jesus, however, refers neither to an objective reality, nor a historical black Jesus. Nevertheless, he is a figure of religious devotion. Other scholars have noted the radical nature of Tupac's black Jesus, but I suggest that they have overlooked, or understated, the unique way that Tupac's black Jesus re-orients our idea of religious truth. Tupac's black Jesus encourages religious truth to be understood as something that addresses individuals instead of regarding it as a Truth that is universally prescriptive, or potentially provable.
\end{abstract}

The phenomenon of Black Jesus incites an interpretive dilemma. ${ }^{1}$ In cases where black Jesus is not understood to be the historical Jesus, he is still taken to be a figure worthy of devotion. The considerable discrepancy between the historical, or "Jewish," Jesus and his black incarnation is a theoretical point in

1 For detailed description of Tupac's black Jesus, please see Michael Eric Dyson, Holler if you Hear Me: Searching for Tupac Shakur (New York: Basic Civitas Books, 2001); Anthony B. Pinn, Noise and Spirit: The Religious and Spiritual Sensibilities of Rap Music (New York: New York University Press, 2003). 


\section{Dustin Zielke}

need of clarification. Such clarification challenges common ways of understanding religious truth and religious reality. In the following, I will argue that the interpretive dilemma of black Jesus can be solved by a fundamental distinction between belief and faith, and attention to the irony of faith. Such a distinction elucidates the different understandings of religious truth which inform faith in black Jesus.

In this article, religious truth refers to the way that many Western individuals tend to relate to religious reality. This is commonly done through a firm belief in that reality's truthfulness-belief corresponds to, and upholds the objective reality of the religious content in question. In this traditional configuration, one imagines that the contents of one's religious beliefs (such as God, Jesus, angels, etc.) exist in a supersensible realm beyond the cosmos. Such an understanding frustrates religious pluralism, for it encourages different religious approaches to vie for the objective truth of their particular beliefs. Black Jesus breaks this deadlock. He does not compete with (in a religious sense) white Jesus or the historical Jesus for his truthfulness. Nevertheless, he garners religious devotion and therefore implies another sense of religious truthfulness (and reality). Black Jesus requires a different way of relating to religious reality, for he is not meant to correspond to an ultimate or objective religious truth.

In current Western culture, belief and faith are often understood as synonymous and interchangeable concepts. If I were to ask a random selection of people if they have faith in God, they would likely understand my question to be whether or not they believed in God's existence. Both faith and belief, despite the subtle nuances of their usage, tend to be taken as a form of either rational or non-rational access to a belief-content, or object of a propositional statement. Religious truth is thereby understood as a truth claim that possibly corresponds to an objective (yet perhaps rationally unverifiable) reality. This is the manner in which many scholars generally interpret black Jesus: as the claims of some fringe groups that the historical Jesus was actually a black man.

My claim that black Jesus signals the loss of objective religious truth should not be understood as the promotion of religious subjectivism or relativism. It could be claimed that people have faith in a black Jesus because it is their opinion that Jesus was black. This, however, is not the kind of rejection I am addressing. In fact, such a claim is still an instance of the kind of objectivity that I am contesting, 
despite its subjectivist overtones. In this case, the content of belief (Jesus' skin color), again taken as a propositional truth, is simply an empty placeholder for whatever the believer wishes to slot into it. Here, Jesus' race is just another instance of an objectification that has been relativized to the point of mere subjective opinion.

Religious subjectivism does not capture the specific challenge that black Jesus provokes. Rather, black Jesus evokes a crisis point at which the truthfulness (as it is traditionally conceived) of religion is at stake. The color of Jesus' skin is taken for granted as not the color of the historical Jesus. Despite the fact that-or perhaps becauseblack Jesus does not resemble historical depictions of Jesus, he is still an icon of devotion. There is a self-reflexive irony in the black Jesus phenomenon that distances devotion or faithfulness to black Jesus from anything resembling a traditional belief. In fact, one must first deny belief in the official figure of Christ in order to have faith in the un-authorized figure of black Jesus. It is this loss of belief in traditional religious truth that makes way for faith in black Jesus. Black Jesus is at once both an icon of devotion and an imaginary figure in the mind of his faithful. In order for this phenomenon to be understood, religious truth needs to be re-conceived.

The phenomenon of black Jesus is not always a hypothesis about the historical Jesus. To illustrate this point, I explore one of the most iconic figures of black Jesus in contemporary popular culture: the rapper Tupac Shakur's (1971-1996) articulation of black Jesus. Exploration into Tupac's idea of black Jesus reveals that faith in this figure lays in a rejection of objective approaches to religious truth, which then result in a loss or redefinition of traditional belief. It is worth noting that there are various formations of black Jesus. For instance, in my travels in rural Nigeria I was intrigued by carved church doors which picture an Ibo Jesus and his Ibo disciples. For the Ibo people, the stories in the Bible occur through an Ibo imagination, which includes black skin. It should also be noted that racial portrayals of Jesus are not limited to black people. Various ethnic groups have their own versions of Jesus. Christian Caucasians, for example, are generally more comfortable with Hollywood depictions of Christ as a blue-eyed, pale-skinnedfigure, than they are with alternative interpretations. $^{2}$

2 See, for instance, Benedict Fitzgerald, Mel Gibson and William Fulco, The 


\section{Dustin Zielke}

I have chosen to focus on Tupac Shakur's black Jesus because he provides a particularly poignant case of the tensions I have outlined above. Black Jesus highlights and embraces the challenge of being devoted to a figure that is readily recognized as imaginary, and it is clear that Tupac thought of his black Jesus as an imaginary figure and yet still maintained a devotional relationship with him. At the heart of the black Jesus phenomenon is careful maintenance of the contradiction between lack of belief in the existence of black Jesus and faithful devotion to him. This is not a paradox that is simply overcome by a leap of faith. Rather, faithfulness occurs precisely in the nonbelieving space that is made available by the denial or absurdity of its truth-content.

In Open Mike, Michael Eric Dyson offers a stimulating and sympathetic account of Tupac's black Jesus. Dyson argues that black Jesus is a railing response and prophetic critique against the dogmatism that Tupac experienced in religious communities. According to Dyson, religions have "no direct access to transcendence" because they are man-made. ${ }^{3}$ They do not know God, have "very little humility" and lack an ultimate viewpoint. Despite these factors however, they treat their beliefs as ultimate:

[T] he belief in revelation and direct connection to providence is evidence of the difficulty of justly adjudicating competing claims of religious knowledge and truth advanced by a wide variety of believers. If such believers claim to know what God wants, then they foreclose, in their heuristic cosmos, the counterclaims of other bearers of knowledge. Or to put it another way, rivalclaims to knowledge are, a priori, viewed as false if they range outside thehermeneutic circle and discursive frame of a given religious community. ${ }^{4}$

Dyson concludes that Tupac wanted to draw attention to the manmade nature of all religious institutions through the figure of black

Passion of the Christ, DVD, directed by Mel Gibson (California: Icon Productions, 2004); George Stevens and James Lee Barret, The Greatest Story Ever Told, DVD, directed by George Stevens (California: George Stevens Productions, 1965, released in DVD format in 2001).

3 Dyson, Open Mike, 283.

4 Ibid. 
Jesus. To Dyson, black Jesus reveals the interpretive and historically embedded nature of all religious conviction and it was Tupac's mission to humble religious beliefs by taking away their ultimacy. While I generally agree with this assessment, it leaves a number of unanswered questions in its wake. It is not enough to say that black Jesus simply challenges traditional belief. How is it that Tupac's black Jesus positively re-assesses and re-imagines religious truth? How is it that black Jesus signals possibilities for faith beyond traditional belief?

By failing to fully explore ways in which black Jesus exceeds a critical position apropos to traditional religion, Dyson does not illustrate how the figure of black Jesus generates new possibilities for religious truth. Because of this, his analysis tends to re-appropriate black Jesus within a traditional Christian worldview. Dyson argues that Tupac's black Jesus pioneered "a religious interpretation that challenged orthodox belief" but also "retained critical elements of conventional faith." ${ }^{5}$ While this does suggest a distinction between belief and faith, it functions on the basis of a return to conventional religious faith. No matter how heterodox black Jesus is for traditional religiosity, he nevertheless gains his legitimacy through conventional merits. This is why, throughout his argument, Dyson is anxious to emphasize the resonances between Tupac's black Jesus and traditional religious figures like the prophet. Dyson suggests that Tupac's black Jesus was the expression of a desire for God in the midst of ghetto life. It was the desire for an "immanent transcendence."

This understanding of Tupac's black Jesus is problematic, for it draws black Jesus into a form of belief that reifies a universally prescriptive notion of religious truth-a notion in direct opposition to what Tupac's black Jesus reveals himself to be. Dyson's argument relies upon a transition from the distinction between belief and faith to the assertion that Tupac's black Jesus signals the desire for an immanent transcendence. This immanent transcendence is meant to conceptualize the repetition of conventional faith in a nonconventional way. It is a desire for the divine re-imagined from the perspective of ghetto life. This desire for transcendence repeats the traditional notion of religious truth as an objective, ultimate reality. Dyson's reading of Tupac's black Jesus thus becomes a black urban

5 Ibid., 287.

6 Ibid. 


\section{Dustin Zielke}

youth's expression of a traditional desire for a transcendent deity. This deity may be dressed in ghetto guise, but is still the traditional image of Christ. In Dryson's interpretation, then, Tupac's black Jesus is a ghettoized version of the traditional content of Christian belief. $\mathrm{He}$ is merely a racialized truth-claim that still signifies an ultimate, objective religious truth. In reifying a traditional way of thinking of religious truth, this interpretation also implies that all truth-seeking subjects should recognize the truthfulness of the "real" divine signified in the guise of black Jesus. Despite its sensitivity to cultural relativism, Dyson's reading is still fundamentally influenced by a prescriptive notion of truth.

Assessments of black Jesus as an expression of traditional faith have spurred my interest in exploring ways in which black Jesus transforms or transcends traditional religious truth, and thereby constitutes a unique occurrence in religious history. I intend to liberate black Jesus by resisting the temptation to fit him into an objectivist framework that interprets him as the expression or sign of a divine reality. Since religious truth (as defined above) is related to religious reality, it is useful to explore how black Jesus alters that relationship. It could be said that black Jesus transforms the mode by which religious reality (truth) is encountered by dislodging the object of belief (beliefcontent) from its esteemed and persistent position. Black Jesus's negative relation to traditional religious worldviews actually signals the loss of or withdrawal from, traditional Christian frameworks. When considered in this regard, it is difficult to positively re-invoke a traditional religious imaginary through black Jesus in the same problematic manner that Dyson does. Instead, such an imaginary can only be recovered in its negativity, for black Jesus symbolizes the loss of this very paradigm.

The positive moment that faith in black Jesus uncovers is not in strict continuity with the past. Rather, it is the emergence of something new in religious life, and reveals a non-prescriptive way of dealing with religious reality and truth. Black Jesus signifies a radical faith without content; a faith which encourages believers to attentively listen for the personalized divine call echoing within their own unique experiences. This personal experience, or existence, may be shared with others, but never as a universal declaration to which all should conform. Faith in black Jesus is a religious devotion to a divine figure that only claims those who have ears to hear. Like seeds to fertile soil, black 
Jesus speaks only to those upon whom his call falls. This personalized claim cannot be secured, objectified or placed in either a concrete or imagined reality. To do so would be akin to creating a foundational, universal and dogmatic body of knowledge. The heterodox nature of Tupac's "thug" Jesus is his signature characteristic. He is baffling to most people that do not share the ghetto cosmos, and even within that cosmos he is still strange. It is the singularity of this figure that constitutes its truth.

Tupac did not think of black Jesus as the historical Jesus. Tupac prayed to black Jesus and regarded him as a personal saint, but consciously created black Jesus after the image of the thuggish personas developed in his "reality rap." For instance, in the song "Black Jesuz," Tupac and his group Outlawz describe their figure of religious devotion as a blunt-smoking, alchohol-drinking and criminally orientated thug. ${ }^{7}$ I have no interest in debating the value of such a figure or the ethical issues involved with this portrayal of black Jesus. My point here is simply to indicate that this figure is clearly an imaginary figure-in Tupac's mind and in ours-that has no apparent correlation with the historical Jesus.

Tupac's black Jesus was forged as an attempt to articulate an alternative to Christianity's historical Jesus. The motivations for this articulation reside in the social anxieties, personal devaluation and feelings of alienation which plague black urban youth. Tupac believed that such feelings are partially the result of interactions with a religion which, despite its claims for universal brotherhood, has historically been complicit with racial oppression. In a verse from the title track of the album Still I Rise, Tupac offers a succinct genealogy of this black angst: "look how it began/ nobody gave a fuck about me/ pistol in my hand/ this cruel world can do without me/ how can I survive/ got me asking white Jesus will a nigga live or die/ cause the Lord can't see us/ in the deep dark clouds of the projects/ ain't no sunshine/ and we only play sometimes." This brief account of Tupac's struggle with Christianity is but one example amongst many in his large discography, and indicates the alienation that praying to a white Jesus

7 Tupac \& Outlawz, “Black Jesuz," in Still I Rise, produced by Johnny J (California: Interscope Records, 1999).

8 Tupac \& Outlawz, "Still I Rise," in Still I Rise, produced by Johnny J (California: Interscope Records, 1999). 


\section{Dustin Zielke}

$\mathrm{d}$ raise in a critical mind like Tupac's.

Shortly after Tupac's violent death in 1996, his childhood pastor, Herbert Daughtry, preached a sermon that further articulates Tupac's alienation from typical Christianity. In this sermon, Daughtry recalls Tupac's lifelong dispute with traditional, white Christianity and paraphrases a conversation he had with Tupac during a prison visit (Tupac was convicted of sexual assault in 1995). According to Daughtry, Tupac expressed the following: "it's hard for me to believe in the same book as the white man. This system which beats you, me, and my people, which does all kinds of evil things all over the world, and claims the Bible as its book-how can I believe the same book?" This recounted conversation highlights Tupac's disillusionment with the Christianity of his youth, and his desire to challenge Christianity's supposedly universal doctrines. Tupac's rejection of the traditional Christian message led to his articulation of black Jesus. This alternative figure satisfied his desire for piety and faith, without the fear of turning a blind eye to Christianity's historical complicity with racial injustices. Rejection of traditional modes of Christian belief thus goes hand in hand with the construction of black Jesus, and the new concept of religious truth he represents.

Although a fictional figure, Tupac's thug Jesus was still an icon worthy of devotion and prayer. In stating that black Jesus is "like a saint that we can trust to help to carry us through," Tupac illustrated how his imaginary Jesus invoked piety according to Tupac's terms. ${ }^{10}$ In one of his final interviews, Tupac talks about black Jesus as his own personal God, and, in doing so, confirms black Jesus's status as a devotional figure. In the interview, Tupac attributes all his talent and success to the blessings black Jesus has bestowed upon him. In order to honour or "repay" those blessings, Tupac asserts that he must be true to himself. He states, "I'm me because of black Jesus, I'm me because of God ... All of our gifts and blessings, and our strengths and our weaknesses come from God, come from black Jesus." ${ }^{\prime 1}$ Similarly,

9 Herbert Daughtry, "Who will Weep for Tupac? A Pastor's Dilemma," Sojourners Magazine, March-April (1997).

10 Shakur, "Black Jesuz."

11 "2Pac - About Black Jesus," video clip (2006), www.youtube.com, http://www. youtube.com/watch?v=YhGxqz2yXu0 (accessed September 15, 2010); "Tupac Interview," video clip (2007), www.youtube.com, http://www.youtube.com/ watch?v=Y8odEyQdUEk (accessed September 15, 2010). 
in the biographical documentary Tupac Shakur: Thug Angel-The Life of an Outlaw, Tupac's reverence for black Jesus is noted in his remark, "I feel like black Jesus got his hand on me and guides me through life to put me where I'm supposed to be." ${ }^{12}$

Tupac's deliberate construction of, and faithful devotion to, a fictional Jesus divorced from any apparent historical reality and/ or baggage, brings attention to the interpretive dilemma that this paper opened with. How are we to understand faith in black Jesus as a devotional figure acknowledged as fictional, rather than as an alternative interpretation of traditional depictions of Jesus? The following discussion will explore this question by focusing on the conceptual distinction between belief and faith. Clarifying these two concepts sheds light on the phenomenon of Tupac's black Jesus, and on the conception of religious truth which fuels it.

Black Jesus is not an object of belief. To understand this, it is helpful to consider the casual way in which belief in God is often spoken of. In much of the Western world, people who say they believe in God also believe in the existence of God. As noted above, when religious truth takes this form, it occurs as a propositional relation to an objective content. In this case, the proposition is the truth-claim that God is an often indefinable entity that exists. His existence-the foundation of peoples' belief in him-is difficult to either prove or disprove, leaving much room for debate. Black Jesus, in contrast, is not an entity whose existence is debatable. The need or impulse to debate his existence is nullified by the acknowledgement that he is an imaginary figure who has no connection to the historical Jesus. It is problematic, then, to think about black Jesus as the object of a propositional statement that corresponds in some way to historical Jesus. Similarly, faith in God is often understood as the act of believing in him, despite not having any rational reason to do so. In this sense, faith provides a form of access to an otherwise objectionable belief. Where reason or rationality cannot cross the chasm to religious truth, faith can. In the philosophy of religion, this way of thinking about God's existence is termed fideism. Because it operates in a propositional structure, the faith leap of the fideist can be aligned with the workings of belief, and therefore does not fit the phenomena of black Jesus as it has been

12 Tupac Shakur: Thug Angel - The Life of an Outlaw, DVD, directed by Peter Spirer (U.S.A: QD3 Entertainment, 2002). 


\section{Dustin Zielke}

explicated here.

Since theories of belief and faith fail to satisfyingly make sense of the black Jesus phenomenon, it is necessary to explore the form of relation that occurs between this phenomenon and its faithful followers. In order to do so, a greater distinction between faith and belief must be made. Belief corresponds with the type of religious truth-claim that I have described as inadequate to the phenomenon of black Jesus, for it posits black Jesus as a possible objective truth that can potentially be proven. If black Jesus were to be regarded as the historical Jesus, belief in him would spur, or be open to historical investigation and reasoned judgment. As I have argued, however, black Jesus does not fit this mold. One does not believe in black Jesus. A more useful term to apply to the phenomenon of black Jesus is faith. It is a peculiar kind of faith, however, that does not engage in debates regarding existence or historical reality. In this sense, faith denies the very structure in which belief operates. The devotion that black Jesus receives is thus best understood as an unbelieving, or ironic faith.

My notion of unbelieving faith is similar to what the Catholic philosopher Gianni Vattimo calls believing in belief. Vattimo does not share my distinction between belief and faith, yet his ideas contain an intriguing and enlightening sense of irony. In a semiautobiographical work entitled Belief, Vattimo calls himself a "halfbeliever" who believes that he believes. ${ }^{13}$ By this he means that he does not believe in Christian doctrine in any matter of fact way. Rather, he tries to transform these doctrines "into concrete principles that are incarnate in one's own existence, and irreducible to a formula." ${ }^{14}$ This is comparable to the way that black Jesus operates in the life of his faithful. In both cases, religious truth does not occur as a proposition, but as an existential engagement with the concrete realities in which we live. It is irony, or Vattimo's ability to have faith without believing in an objective content, which informs my understanding of faith in black Jesus, and serves as a foundation for my notion of unbelieving faith.

Irony is also an area of exploration for the Christian philosopher and theologian Søren Kierkegaard, who writes, "if you wish to be and remain enthusiastic, then draw the silk curtains of facetiousness

13 Gianni Vattimo, Belief (Oxford: Polity Press, 1999).

14 Ibid., 77. 
(irony's), and so hide your enthusiasm." ${ }^{15}$ The role played by irony in his novella Repetition sheds light on the type of unbelieving faith within which devotion to black Jesus is grounded. The narrator of the story tells of a young man who falls in love with a young girl. Soon, the young man begins to show signs of falling out of love with the girl, and begins to remove himself from the relationship by becoming introspective about it. The narrator explains, "he was in love ... that was evident-and yet at once, on one of the first days of his engagement, he was capable of recollecting his love. Substantially he was through with the whole relationship. Before he begins he has taken such a terrible stride that he has leapt over the whole of life"16 The narrator advises his young friend to pretend that he has found another mistress, break off his relations with the girl, and hope that the strength of his love is enough to repeat the task of attempting to regain her affections. Through the ploy of irony, he would then gain the necessary character and fortitude to allow his love to grow. The young man ultimately does not take the narrator's advice and the relationship ends badly. The narrator summarizes the young man's problem in this way: "his soul lacked the elasticity of irony." ${ }^{17}$

The "elasticity of irony," or the ability to engage meaningfully and sincerely with referents that are not to be regarded as real or objective, is a useful tool for mapping out the phenomenon of faith in black Jesus. It speaks to the flexibility of imagination and faith reverence to a fictional figure requires. In order for black Jesus to be taken seriously, there must be a loss of belief in Jesus as he has been historically portrayed in the West, and a willingness to trust in a religious truth that is not tied to anything concrete. Tupac never intended for his figure of black Jesus to operate in a prescriptive notion of truth; he did not demand that other Christians have the same faith in black Jesus as he did. The sense of irony, and unbelieving faith which he accepted, however, did not equate to an inability for black Jesus to be heard by others. Black Jesus, according to Tupac's formulation, could especially speak to those who shared Tupac's ghetto cosmos. The religious truth supporting Tupac's black Jesus was not as much prescriptive as much

15 Søren Kierkegaard, The Soul of Kierkegaard: Selections from His Journal, edited by Alexander Dru (New York: Courier Dover, 2003), 126.

16 Søren Kierkegaard, A Kierkegaard Anthology, edited by Robert Bretall (New Jersey: Princeton University Press, 1973), 135.

17 Ibid. 
as it was open to certain "elect" individuals which Tupac called thugs.

Tupac's faith in black Jesus was informed by his experiences growing up in a predominantly black American ghetto. It would be difficult for people who do not come from a similar environment to appreciate the truth and reality of Tupac's black Jesus, for he speaks primarily to what Tupac refers to as fellow thugs. Although black Jesus emerges out of shared ghetto experiences, however, he only speaks to individuals, and his words change from person to person. Although, as previous studies into black Jesus have shown, there is a temptation to boil the phenomenon of black Jesus down to a matter of re-interpretation or alternative belief, I argue that doing so overlooks ways in which the powerful relationship between irony and faith can manifest themselves in people's lives. It also overlooks the ways in which faith can shake itself free from traditional Christian belief and the approaches to religious reality which feed that belief.

\section{Bibliography}

Tupac Shakur: Thug Angel-The Life of an Outlaw. DVD. Directed by Peter Spirer. U.S.A: QD3 Entertainment, 2002.

Daughtry, Herbert. "Who Will Weep for Tupac? A Pastor's

Dilemma." Sojourners Magazine, March-April 1997.

Dyson, Michael Eric. Holler if you Hear Me: Searching for Tupac

Shakur. New York: Basic Civitas Books, 2001.

Dyson, Michael Eric. Open Mike: Reflections on Philosophy, Race, Sex, Culture, and Religion. New York: Basic Civitas Books, 2003.

Fitzgerald, Benedict, Mel Gibson and William Fulco. The Passion of the Christ. DVD. Directed by Mel Gibson. California: Icon Productions, 2004.

Kierkegaard, Søren. The Soul of Kierkegaard: Selections from his Journal. Edited by AlexanderDru. New York: Courier Dover, 2003. 
Pinn, Anthony B. Noise and Spirit: The Religious and Spiritual

Sensibilities of Rap Music. New York: New York University Press, 2003.

Shakur, Tupac and Outlawz. "Black Jesuz." In Still I Rise. Produced by Johnny J. California: Interscope Records, 1999.

Shakur, Tupac and Outlawz. "Still I Rise." In Still I Rise. Produced by Johnny J. California: Interscope Records, 1999.

Stevens, George and James Lee Barret. The Greatest Story Ever Told. DVD. Directed by George Stevens. California: George Stevens Productions, 1965. Released in DVD format in 2001.

"2Pac-About Black Jesus." Video clip (2006). www.youtube.com. http://www.youtube.com/watch?v=YhGxqz2yXu0. Accessed September 15, 2010.

“Tupac Interview.” Video clip (2007). www.youtube.com. http://www.youtube.com/watch?v=Y8odEyQdUEk. Accessed September 15, 2010.

Vattimo, Gianni. Belief. Oxford: Polity Press, 1999. 